\title{
Mycelia Growth of Shiitake (Lentinula edodes) on 4-Wood Species from Leguminaceae Family
}

\author{
Dahayu Ratnanindha, Johanes Pramana Gentur Sutapa, and Denny Irawati
}

\begin{abstract}
Cultivation of Shiitake mushroom (Lentinula edodes) in Indonesia has not been developed yet, due to its low productivity. It happens because of the limited information of the good ways on cultivation Shiitake in Indonesia. One of the factors that affect the growth of mushroom is the media. In Indonesia, the information about the media composition by using various species of wood have not been found yet. Therefore, this research was conducted to determine the effect of using different wood species to the growth of Shiitake. This study used four wood species from the leguminaceae family, those were: Gamal (Glicidia sepium); Johar (Samanea saman); Leucaena (Leucaena leucocephala); and Sengon (Falcataria moluccana). Those were used as the media by adding $12.5 \%$ (w/w) of rice bran and $6 \%(\mathrm{w} / \mathrm{w})$ of $\mathrm{CaCO}_{3}$, and adjusting the moisture content by adding the distillate water to 65,70 , and $75 \%$. Then, the media was put in to the petridisk $(\varnothing 90 \mathrm{~mm})$ and inoculated with Shiitake mushroom. During the mycelia growth, the length of mycelia was measured every 2 days until fifty days, and then glucosamine content was analyzed. In addition, chemical analysis was also conducted to each media. The results showed that different wood species resulted different chemical content of media, except the acid soluble lignin content. The growth rate of mycelia was affected by the moisture content of media, meanwhile the glucosamin content is influenced by the moisture content and various species of wood. The best combination to cultivate the Shiitake mushroom was by using media made of gamal with $70 \%$ moisture content. There were positive correlation among the ethanol-toluen extracts content and the mycelia growth, however there was negative correlation among the hemicelullose content the mycelia growth.
\end{abstract}

Keywords: Shiitake mushroom, Leguminoceae, mycelial growth, moisture content, media's chemical content.

\section{Introduction}

Shiitake (Lentinula edodes) is an edible mauhroom which is famous in Japan and may called also as Chinese Black Mushroom. This mushroom posses high trade value, however, unfortunately this Shiitake mushroom cultivation is not so well known in Indonesia and still needs many information on its development.

Generally mushroom's growth is affected very much by media condition such as, species which is used, moisture content, media composition, $\mathrm{pH}$, and the environment condition of the media. The previous research results on ear-mushroom which was cultivated by 3 different species showed that very significant difference of micellium growth rate on each media from 3 different wood species was found (Irawati et al. 2012). For Shiitake it self, the optimum environment condition of growth site on temperature $5 \sim 35^{\circ} \mathrm{C}$ and $6 \sim 25^{\circ} \mathrm{C}$ for its fruiting bodies' growth, with optimum humidity among 95 100\% (Widyastuti 2009). On the other hand, the proper media condition for Shiitake growth in Indonesia has not been known well. Recently, Shiitake is cultivated by people by using sengon media only, however, sometimes in the areas which are not the centre of sengon faces difficulties to get that wood. To reduce the dependency on sengon, therefore, other wood species which can be used as Shiitake media need to be found as an alternative.

In Indonesia some other wood species which are classified into family Leguminoceae are supposed to posses good characteristics for mushroom growth. Species from family Leguminoceae is usually easy to be found in community's yard especially in country side. Community plants species from Leguminoceae very much because they use the leaves as cattle feed or to fertilize soil. Information about wood species in Indonesia which is suitable for Shiitake mushroom cultivation and also physical condition of the media suh as moisture content have not been found yet. To support the development of Shiitake mushroom cultivation in Indonesia, therefore, research about the effect of various wood species especially which are classified as family Leguminoceae and optimum media's moisture content was conducted.

\section{Materials and Methods}

\section{Fungus and Substrate Materials}

Seed of Shiitake mushroom F1 (pure culture) was obtained from kelompok tani Sedyo Lestari, Bantul, Yogyaarta. Wood meal (9 80 mesh) of 4-wood species from family Leguminaceae which are Gamal (Gliricidia sepium), Johar (Samanea saman), Lamtoro (Leucaena leucocephala), and Sengon (Falcataria moluccana) were used as the basal cultivation substrates. Commercial rice bran (9 80 mesh size) was used as a nutritive additive. Chemical contents of wood and rice bran whic are used are shown on Table 1. 
Table 1. Chemical componen content of 4-wood species and rice bran (\%).

\begin{tabular}{lrrrrr}
\hline Chemical content & \multicolumn{1}{c}{ Sengon } & \multicolumn{1}{c}{ Gamal } & \multicolumn{1}{c}{ Johar } & \multicolumn{1}{c}{ Lamtoro } & \multicolumn{1}{c}{ Rice bran } \\
\hline Ethanol-toluene extractives & $2.92 \pm 0.35$ & $5.18 \pm 0.14$ & $3.12 \pm 0.40$ & $1.98 \pm 0.20$ & $6.87 \pm 0.10$ \\
Holocellulose & $80.78 \pm 0.63$ & $83.85 \pm 0.12$ & $84.97 \pm 0.55$ & $83.56 \pm 1.07$ & $81.58 \pm 0.82$ \\
a-cellulose & $45.34 \pm 1.11$ & $53.72 \pm 0.55$ & $47.15 \pm 0.44$ & $43.69 \pm 0.97$ & $51.4 \pm 0.10$ \\
Hemicellulose & $35.45 \pm 1.62$ & $30.12 \pm 0.21$ & $37.82 \pm 0.06$ & $39.87 \pm 1.02$ & $30.18 \pm 0.91$ \\
Klason lignin & $23.30 \pm 0.30$ & $27.47 \pm 0.39$ & $20.16 \pm 0.79$ & $22.00 \pm 0.28$ & $36.73 \pm 0.20$ \\
Acid soluble lignin & $2.83 \pm 0.08$ & $1.35 \pm 0.05$ & $2.60 \pm 0.01$ & $1.48 \pm 0.03$ & $1.8 \pm 0.034$ \\
Hot water soluble extractives & - & - & - & - & $19.5 \pm 0.20$ \\
\hline
\end{tabular}

Wood meal and commercial rice bran were mixed in a weight ratio of 8:1. Moisture content (MC) of wood meal and rice bran was determined by $103 \pm 2^{\circ} \mathrm{C}$ and scaling them until we have constant weight. Calcium carbonate was added at a concentration of $6 \%(\mathrm{w} / \mathrm{w})$ to adjust the $\mathrm{pH}$ of the cultivation substrate to between 6 and 7 . MC of the substrate was adjusted to 65,70 , and $75 \%$ by adding tap water.

\section{Chemical Components of Media}

Chemical components of media was determined before cultivation. Extraction with organic solvents was performed to determine the quantities of holocellulose, acellulose, Klason lignin, and ash. Before chemical analysis, the samples were ground with a rotary speed mill and then sieved through 40 80 mesh size. Subsequently, the samples were dried in an oven at $45^{\circ} \mathrm{C}$. Extraction with organic solvents was performed as follows: $5 \mathrm{~g}$ of sample was extracted with $120 \mathrm{ml}$ of a mixture of ethanol and toluene $(1: 2, \mathrm{v}: \mathrm{v})$ by a Soxhlet extractor for $6 \mathrm{~h}$. The amounts of Klason lignin, holocellulose, and a-cellulose were determined by ordinary methods (Carrier et al. 2011; Irawati et al. 2013). To determine the ash content, a $1 \mathrm{~g}$ sample was heated in a muffle furnace at $600^{\circ} \mathrm{C}$ for $2 \mathrm{~h}$, and then, after cooling in a desiccator, it was reheated at $600^{\circ} \mathrm{C}$ for $1 \mathrm{~h}$. For all chemical component analyses, 3 replications were performed for each sample.

\section{Mycelial Growth Rate}

To measure the mycelial growth rate, $20 \mathrm{~g}$ of cultivation substrate was packed in a Petri dish $(90 \mathrm{~mm}$ diameter) by following the method in published paper before (Irawati et al. 2012). Five replications were performed for each wood meal substrate. The substrates were subsequently autoclaved at $121^{\circ} \mathrm{C}$ for $20 \mathrm{~min}$, and inoculated with mycelial plugs (5 mm diameter) of Shiitake, previously grown on potato dextrose agar medium. The culture was maintained at $25^{\circ} \mathrm{C}$ in the dark. Colony diameter was measured every 2 days in four directions until the mycelia reached the edge of each Petri dish.

\section{Glucosamine Content}

To determine the glucosamine content in the mycelium, $5 \mathrm{~g}$ of cultivation substrate was packed in a Petri dish (45 $\mathrm{mm}$ diameter). Chitin content in the mycelium was assayed by the method of Braid and Line (1981) and 3 repetitions were performed for each sample. To degrade fungal chitin into $\mathrm{N}$-acetyl glucosamine, $1 \mathrm{~g}$ of the dry sample after 50 days of culture was hydrolyzed with $5 \mathrm{ml}$ of $5 \mathrm{M} \mathrm{HCl}$ at $80^{\circ} \mathrm{C}$ for $20 \mathrm{~h}$. The absorbance of the characteristic bluish green color was measured at $630 \mathrm{~nm}$ using a spectrophotometer. The calibration curve was drawn with N-Acetyl-D-(+)-glucosamine (Wako Pure Chemical Co., Japan) as a standard at concentrations of $0,10,20$, and 30 $\mathrm{mg} / \mathrm{ml}$.

\section{Results and Discussion}

\section{Chemical Contents of Media}

Originaly, chemical content of media was different with chemical content of wood (Table 1), because there were rice bran and $\mathrm{CaCO}_{3}$ addition into the media. Chemical content of media, then, was used as basic calculation and analysis. Table 2 shows that difference of wood species significantly affected to ethanol- toluene extractives content, hot water soluble extractive content, holocellulose, aselulosa, hemicellulose, and Klason lignin, but it did not affect to acid soluble lignin. Media made of johar wood showed the highest ethanol-toluene extractives content (8.84\%) and hot water soluble extractives content $(16.3 \%)$ indicating that media made of johar wood is estimated to posses substrate contents such as waxes, fat, resin, tannin and eter components which are soluble into high polar and non-polar extractives and also high tannin content, gum, sugar, and colour substrates which are soluble in the water.

Holocellulose, a-cellulose, dan hemicellulose are carbohydrate polymer which are avaliable in the wood. The highest holocellulose and a-celulose which were found in media made of wood were $84.67 \%$ and $60.04 \%$, respectively. Cellulose is the main polymeric component of the plant cell wall, the most abundant polysaccharide on earth, and an important renewable resource. Basidiomycetous fungi belong to its most potent degraders because many species grow in environment rich in cellulos (Baldrian and Valaskova 2008). Some edible mushroom species which are classified into Basidiumycetous. Hemicellulose content was calculated based on substraction between holocellulose content and a-cellulose. Table 2 shows that the highest hemicellulose content was found in media made of sengon wood $28.73 \%$. During wood degradation, generally, hemicellulose which is 
polysaccharide with short sugar structures is degraded at first (Higuchi 1985).

The highest Klason lignin was found in the media made of gamal wood $(28.56 \%)$ and it was statistically different with the media made of other wood species. Przybylowicz and Donoghue (1990) pointed out that lignin has special role in Shiitake mushroom growth. Shiitake mushroom also obtains the nutritions needed from lignin degradation process result. Shiitake mushroom's hypha extracts enzymes which are able to destroy the undegradable materials such as cellulose and lignin from the wood and change them into the simple monomers then give back to the hypha of fungi as food. Meanwhile, no significant difference was found in the acid soluble lignin content among the wood species, statistically.

Table 2. Chemical contents of media from 4 wood species (\%).

\begin{tabular}{|c|c|c|c|c|c|}
\hline Chemical content & Sengon & Gamal & Johar & Lamtoro & ANOVA Analysis \\
\hline Ethanol-toluene extractives & $4.45 \pm 0.02^{\mathrm{a}}$ & $8.36 \pm 0.11^{c}$ & $8.84 \pm 0.04^{d}$ & $5.73 \pm 0.12^{b}$ & ** \\
\hline Hot water soluble extractives & $5.06 \pm 0.16^{b}$ & $11.42 \pm 0.13^{c}$ & $16.3 \pm 0.19 d$ & $2.95 \pm 0.06^{a}$ & ** \\
\hline Holocellulose & $81.59 \pm 0.70 c$ & $75.85 \pm 0.13^{b}$ & $70.33 \pm 0.37 a$ & $84.67 \pm 0.99 d$ & ** \\
\hline a-cellulose & $52.86 \pm 0.25^{a}$ & $58.97 \pm 0.50^{\mathrm{b}}$ & $51.63 \pm 0.76^{a}$ & $60.04 \pm 0.64^{b}$ & ** \\
\hline Hemicellulose & $28.73 \pm 0.78 \mathrm{c}$ & $16.89 \pm 0.48^{a}$ & $18.7 \pm 0.84^{a}$ & $24.63 \pm 1.61^{b}$ & ** \\
\hline Klason lignin & $22.15 \pm 1.00^{a}$ & $28.56 \pm 0.30^{b}$ & $23.77 \pm 0.14^{a}$ & $22.32 \pm 0.96^{a}$ & ** \\
\hline Acid soluble lignin & $0.03 \pm 0.002$ & $0.03 \pm 0.001$ & $0.03 \pm 0.004$ & $0.03 \pm 0.001$ & ns \\
\hline
\end{tabular}

The same superscript letter followed by the average value in the same row shows no significant difference among the four tree species by Tukey-Kramer test at the $5 \%$ level. $n=3 . \pm=$ Standard deviation.

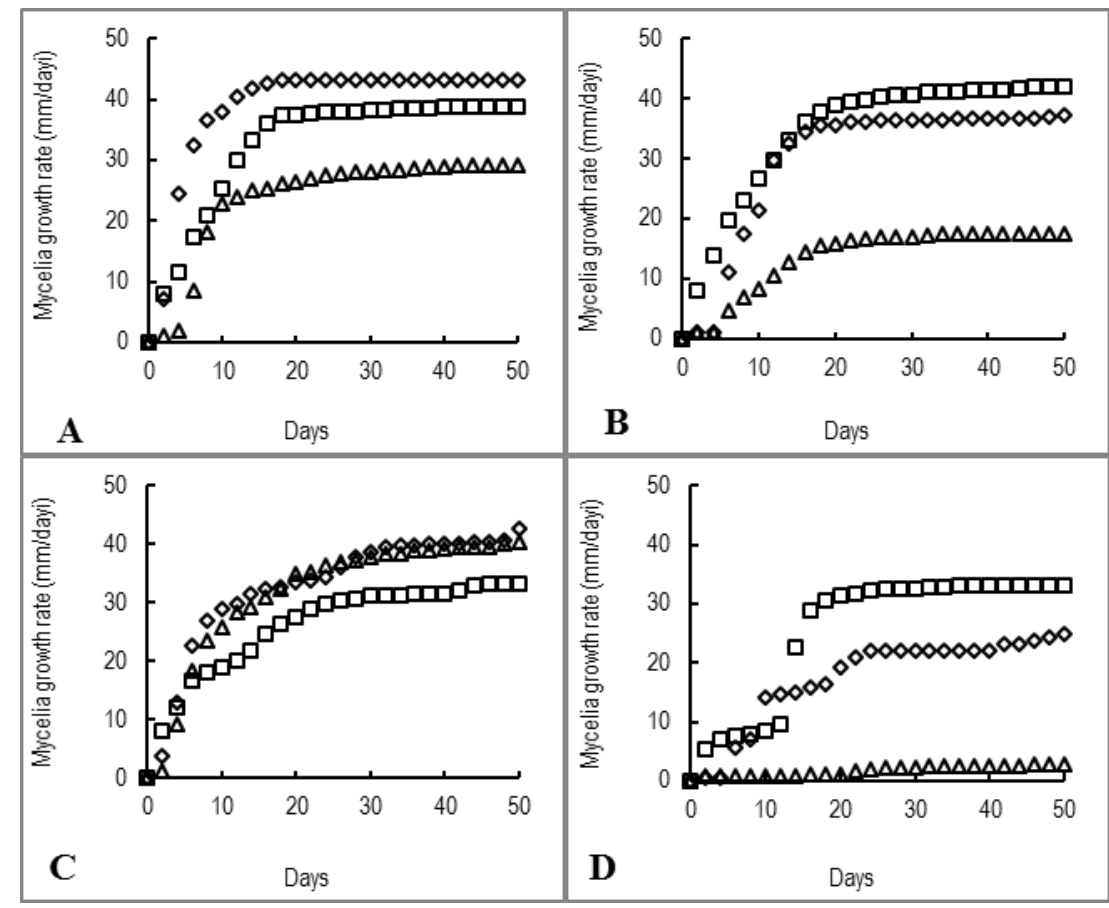

Figure 1. Graphic of Shiitake mushroom's mycellia growth. Remarks: (A) Gamal; (B) Johar; (C) Lamtoro; (D) Sengon. Diamond (65\%); Square (70\%); Triangle (75\%).

\section{Mycellia Growth Rate}

Mycellia growth rates per 2 days on each types of substrate with different moisture content were shown in Fig. 1. Those 4 graphics showed that the average length of mycellia growth rate increased rapidly on the beginning of growth period and then it remained constant relatively. The average value of mycellia growth rate on this research was ranged from 0.61 to $3.32 \mathrm{~mm} /$ day. This value is included in the range of another mushroom growth rate which is Auricularia polytrica, which has growth rate among 1.80 3.21 mm/day (Irawati et al. 2012). Statistic analysis results of mycellia growth rate on factor wood species and moisture content showed no significant effect on factor wood species and the interaction of those 2 factors, however, factor moisture content alone very significantly affected to mycellia growth rate. 


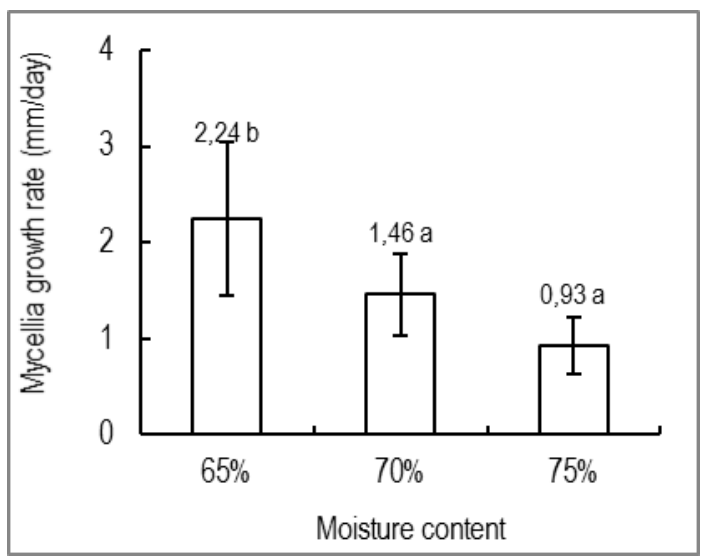

Figure 2. Graphic of mycellia growth in 3 different moisture contents.

Fig. 2 shows the values of mycellia growth rate on $65 \%$ moisture content is significantly different with mycellia growth rate on $70 \%$ and $75 \%$ moisture content. Whereas no significant difference was found on the values of mycellia growth rate on $70 \%$ moisture content and $75 \%$ moisture content, statistically. The highest mycellia growth rate value was found media with $65 \%$ moisture content which is 2.24 $\mathrm{mm} /$ day. Actually, according to the previous research results, Shiitake is classified in mushrooms with high water activity, means Shiitake mushroom will grow well on media which has high moisture content (Hu et al. 2004), however it also pointed out that water activity of Shiitake mushroom is also affected wood physical properties as media. Wood with high water activity (easy to absorp water) needs high water addition in order to be good as Shiitake mushroom cultivation media, and vice versa. In this research, the woods used were supposed as species with low water activity, so the optimum water addition was $65 \%$. Widyastuti (2009) pointed out that moisture content of sawdust media for Shiitake mushroom vegetative growth is ranged from 60 to $75 \%$. Mycellia growth rate of Shiitake on media made of sugi sawdust increases along with the increment of moisture content of media from 65 to $75 \%$, it was also happenned on media made of konara wood (Hu et al. 2004).

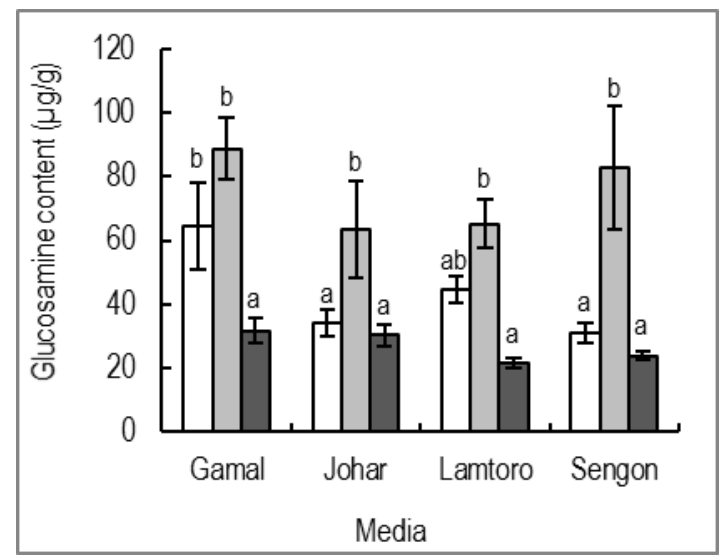

Figure 3. Graphic of glucosamine content of Shiitake mushroom's mycellia on 4 types of media. White (65\%). Light gray $(70 \%)$. Dark gray $(75 \%)$.

\section{Glucosamine Content}

Glucosamine content was measured to determine the number of mycellia on media substrate before fruiting bodies phase. No branches polymer from N-acetyl-Dglucosamine (chitin) is component which is avalilable on mushroom's cell wall, generally. Acid hydrolysis to kitin will disintegrate glucosamine and comparison between glucosamine and mycellia dry-weight can be determined and used to calculate mushroom biomass in the media or substrate (Jones and Worral 1995). Ohga (2000) pointed out that the bigger glucosamine content makes the number of mycellia in the media substrate more abundant.

The average value of glucosamine content in this research was ranged among 21.56 88.81 $\mu \mathrm{g}$. Fig. 3 showed that media glucosamine content made of 4 wood species with $70 \%$ moisture content posses highest value compared to media with different moisture content indicating that $70 \%$ moisture content is the most suitable moisture content for Shitake mushroom's mycellia growth on 4 media. Media moisture content affects to mushroom growth, because ideal moisture content in the baglog will yield which 
is not too wet or dry. Too high moisture content in the baglog may cause that baglog will be decomposed quickly, in contrary, less moisture content in the baglog also causes not optimum mushroom growth (Meinanda 2013).

\section{Correlation between Chemical Content to Growth Rate and Glucosamine Content}

Wood mushrooms, in their growth period, generally obtain the nutritions from the wood decomposition of their media. The main components of wood composer which are cellulose, hemicellulose and lignin are carbon resources which are needed for wood mushroom's growth (Przybylowicz and Donoghue 1990). However, Przybylowicz and Donoghue (1990) also added that resins and phenolic compounds may inhibit the mushroom growth on wood media both hardwood or softwood because those kind of extractives are very difficult to be degraded by wood mushroom, generally.

Correlation analysis results between chemical content of sawdust media and mycellia growth rate and glucosamine content are presented in Table 3. The average of Shiitake mycellia growth rate in this research positively correlated with ethanol-toluene extractives content and negatively correlated with hemicellulose content of the media. This results indicated that media with high ethanol-toluene extractives content can be grown by mushroom mycellia faster. Whereas on the media have high hemicellulose content mushroom mycellia grew slower. Generally, extractives content (especially ethanol-toluene extractives content) may cause negative impact to mycellia growth (Przybylowicz and Donoghue 1990), however, Shiitake mushroom in this research used substrates in ethanoltoluene extractives as carbon resources for its growth. Shiitake mushroom is classified as white-rot fungi therefore Shiitake mushroom secretes ligninase enzyme to degrade lignin or other phenolic compounds in the media. At first, Shiitake mushroom is supposed to use the simple compounds in the extractives and then degrade lignin which is more complex. This matter also explains about the high correations between lignin content and growth rate or glucosamine content, however, statistically those correlation coefficients are not significant. Negative correlation between mycellia growth and hemicellulose content pointed out that Shiitake mushroom does not use hemicellulose of the media for its growth. The same tendency was also happenned on holocellulose although the correlation coefficient was not significant. Shiitake mushroom does not secrete hemicellulose enzyme to degrade cellulose, allegedly.

Table 3. Correlation of chemical content to growth rate and glucosamine content.

\begin{tabular}{lcc}
\hline Chemical components & Growth rate & Glucosamine content \\
\hline Ethanol - toluene extractives & $0.973^{*}$ & $0.350 \mathrm{~ns}$ \\
Hot water soluble extractives & $0.853 \mathrm{~ns}$ & $0.169 \mathrm{~ns}$ \\
Holocellulose & $-0.821 \mathrm{~ns}$ & $-0.141 \mathrm{~ns}$ \\
a-cellulose & $0.042 \mathrm{~ns}$ & $0.476 \mathrm{~ns}$ \\
Hemicellulose & $-0.988^{*}$ & $-0.534 \mathrm{~ns}$ \\
Klason lignin & $0.825 \mathrm{~ns}$ & $0.927 \mathrm{~ns}$ \\
\hline${ }^{*}$
\end{tabular}

${ }^{* *}=$ Significant at $1 \%$ level. $\mathrm{ns}=$ Not significant.

\section{Conclusions}

The growth rate of mycelia was affected by the moisture content of media, meanwhile the glucosamin content is influenced by the moisture content and various species of wood. The highest glucosamine content was found in $70 \%$ moisture content for all species, although the highest mycelia growth rate was found in $65 \%$ moisture content. The best combination to cultivate the Shiitake mushroom was by using media made of gamal with $70 \%$ moisture content. There were positive correlation among the ethanol-toluen extracts content and the mycelia growth, however there was negative correlation among the hemicelullose content the mycelia growth.

\section{Acknowledgment}

This research was partly supported by research grant of Faculty of Forestry universitas Gadjah Mada.

\section{References}

Baldrian, P. and V. Valaskova. 2008. Degradation of cellulose by basidiomycetous fungi. FEMS Microbiol Rev. 32: 501-521.

Braid, G. H. and M. A. Line. 1981. A sensitive chitin assay for the estimation of fungal biomass in hardwoods. Holzforschung 35: 10-15.

Carrier, M.; A. Loppinet-Serani; D. Denux; J. M. Lasnier; F. Ham-Pichavant; F. Cansell; and C. Aymonier. 2011. Thermogravimetric analysis as a new method to determine the lignocellulosic composition of biomass. Biomass and Bioenergy 35: 298-307. 
Higuchi, T. 1985. Biosynthesis and Biodegradation of Wood Components. Wood Research Institute Kyoto University. Uji, Kyoto, Japan.

Hu, C.; S. Meguro; and S. Kawachi. 2004. Effect of Physical Properties of Wood on The Water Activity of Wood Meal media for the cultivation. J. Wood Sci. 50: 365370.

Irawati, D.; C. Hayashi; Y. Takashima; S. Wedatama; F. Ishiguri; K. lizuka; N. Yoshizawa; and S. Yokota. 2012. Cultivation of The Edible Mushroom Auricularia polytricha Using Sawdust - Based Substrate Made of Three Indonesian Commercial Plantation Species, Falcaria moluccana, Shorea sp., and Tectona grandis. Micologia Aplicada International 24: 33-41.

Irawati, D.; Y. Takashima; C. Ueda; J.P.G Sutapa; S.N. Marsoem; F. Ishiguri; K. lizuka; N. Yoshizawa; and S. Yokota. 2013. Ozone treatment of spent medium from Auricularia polytricha cultivation for enzymatic saccharification and subsequent ethanol production. J. Wood Sci. 59: 522-527.
Jones, L. H. and J.J. Worrall. 1995. Fungal Biomass in Decayed Wood. Mycologia 87: 459-466.

Meinanda, I. 2013. Panen Cepat Budidaya Jamur. Padi. Bandung.

Ohga, S. 2000. Influence of wood species on the sawdustbased cultivation of Pleurotus abalonus and Pleurotus eryngii. J. Wood Sci. 46: 175-179.

Przybylowicz, P; J. Donoghue. 1990. Shiitake Growers Handbook. Kendal Hunt Publishing Company: Dubuque, Lowa.

Widyastuti, N. 2009. Jamur Shiitake. Lily Publisher: Yogyakarta.

Dahayu Ratnanindha, Johanes Pramana Gentur Sutapa

Coresponding author:

Denny Irawati

Chemical Conversion of Biomaterial Laboratory

Faculty of Forestry, Universitas Gadjah Mada, Yogyakarta.

E-mail : dirawati@ugm.ac.id 